\title{
Pengaruh Kompetensi, Kompensasi Dan Kepuasan Kerja Terhadap Motivasi Kerja Relawan Taruna Siaga Bencana Pada Dinas Sosial Kabupaten Bima
}

\author{
Rijal Mukhlis \\ Universitas Terbuka \\ 530013063@ecampus.ut.ac.id
}

\begin{abstract}
Abstrak. Keberadaan sumber daya manusia (SDM) pada organisasi tidak bisa digantikan dengan mesin, dimana keberlanjutan dan ketercapaian tujuan suatu organisasi SDM menjadi instrumen kunci. Bagi organiasi, penting untuk mengetahui motif dan motivasi yang diinginkan anggota dalam bekerja. Salah satu motivasi dan dorongan dalam bekerja karena keinginan untuk memenuhi kebutuhan, baik kebutuhan yang disadari (Concius Needs), kebutuhan materi dan non materi, maupun kebutuhan fisik atau rohani, termasuk untuk mengabdikan dan bekerja sebagai Relawan Taruna Siaga Bencana (TAGANA) Pada Dinas Sosial Kabupaten Bima. Motivasi kerja secara teoritis dapat disebabkan oleh berbagai faktor, baik faktor internal maupun faktor eksternal. Faktor internal seperti kompetensi kerja, dan kepuasan kerja. Sedangkan faktor eksternal seperti kompensasi yang diterima sebagai balas jasa atas tugas sebagai relawan TAGANA. Hasil penelitian menunjukkan kompetensi memiliki pengaruh terhadap motivasi. Artinya semakin tinggi kompetensi maka semakin tinggi pula motivasi kerja TAGANA. Hasil penelitian ini mendukung hasil penelitian Murgianto dan Sulasmi (2016) yang menyatakan bahwa kompetensi memiliki pengaruh langsung dan tidak langsung terhadap motivasi dan kepuasan kerja. Semakin baik kompetensi maka akan semakin baik motivasi kerja atau untuk meningkatkan motivasi kerja TAGANA harus dibarengi dengan peningkatan kompetensi kerja.
\end{abstract}

Keywords: Motivasi Kerja, Kompetensi, Kompensasi dan Kepuasan Kerja TAGANA.

\section{PENDAHULUAN}

Keberadaan TAGANA sangat dibutuhkan mengingat keadaan geografis atau alam di Indonesia sangat rentan sehingga sering terjadi musibah atau bencana, baik bencana alam, bencana sosial maupun kegagalan tekhnologi, seperti gempa bumi, letusan gunung berapi, tanah longsor, banjir, kebakaran, kerusuhanan dan lain-lain, sebagaimana yang ditampilkan dalam grafik trand bencana alam pada gambar 1.1 dibawah ini.

Gambar.1.1

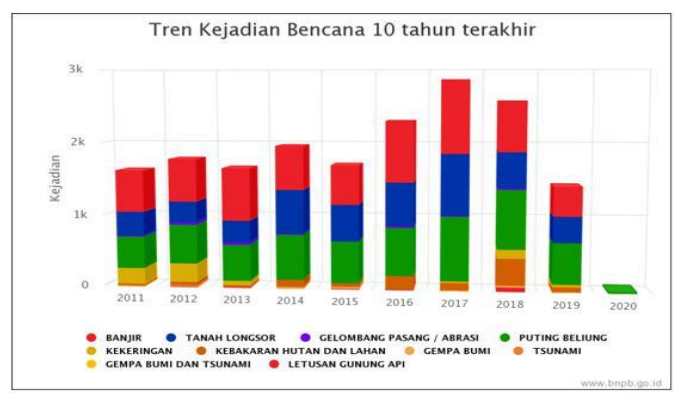

Sumber: BNPB, 2020
Meningkat drastisnya minat masyarakat untuk menjadi relawan TAGANA menjadi hal menarik untuk dikaji, karena pada prinsipnya tugas utama relawan TAGANA harus selalu siap-siaga diterjunkan membantu korban bencana yang artinya berada di lokasi bencana sementara orang-orang pada umumnya justru berupaya untuk menjauh dari lokasi bencana. Insentif relawan TAGANA pun tidak sebanding dengan beban dan risiko kerja. Dari sekian banyak yang berminat relawan TAGANA hanya sebagian saja yang diterima dan mendapatkan Surat Kerja (SK) dari Dinas Sosial Kabupaten Bima, namun tidak jarang dijumpai relawan TAGANA yang menunjukkan motivasi kerja yang rendah, seperti jarang hadir, sering minta ijin, mengeluh pada saat melaksanakan tugas di lokasi bencana.

Menyadari keadaan tersebut di atas pihak pemerintah daerah melakukan seleksi 
Jurnal Ilmiah Mandala Education

http://ejournal.mandalanursa.org/index.php/JIME/index

terakreditasi Peringkat 4 (No. SK: 36/E/KPT/2019)

terhadap Relawan Taruna Siaga Bencana termasuk melalui Dinas Sosial Kabupaten Bima. Selama keterlibatan sebagai relawan penaggunglangan bencana maka Dinas Sosial menilai keterampilan dan kinerjannya sebagai dasar memberikan Surat Keputusan sebaga relawan Taruna Siaga Bencana (TAGANA).

Tabel.1.1 : Relawan yang Mendaftar

\begin{tabular}{|c|c|c|c|c|c|c|c|c|}
\hline \multirow[b]{2}{*}{ No } & & \multicolumn{5}{|c|}{ PEMINTA RELAWAN TAGANA } & \multirow[b]{2}{*}{2019} & \multirow{2}{*}{$\%$} \\
\hline & 2016 & $\%$ & 2017 & $\%$ & 2018 & $\%$ & & \\
\hline 1 & 93 & 64 & 102 & 91 & 192 & 53 & 253 & 75 \\
\hline
\end{tabular}

Sumber: Diolah peneliti berdasarkan data lamaran menjadi relawan TAGANA,

2019.

Berdasarkan paparan di atas menjadi alasan utama peneliti untuk melakukan penelitian "Faktor-Faktor Yang Mepengaruhi Motivasi Kerja Relawan Taruna Siaga Bencana (TAGANA) Dinas Sosial Kabupaten Bima".

\section{Perumusan Masalah}

Berdasarkan latar belakang masalah di atas maka adapun yang menjadi rumusan permasalahan dalam penelitian ini adalah sebagai berikut :

- Apakah Kompetensi Berpengaruh Terhadap Motivasi Kerja Relawan Taruna Siaga Bencana (TAGANA) Dinas Sosial Kabupaten Bima?

- Apakah Kompensasi Berpengaruh Terhadap MotivasiKerja Relawan Taruna Siaga Bencana (TAGANA) Dinas Sosial Kabupaten Bima?

- Apakah Kepuasan Kerja Berpengaruh Terhadap Motivasi Kerja Relawan Taruna Siaga Bencana (TAGANA) Dinas Sosial Kabupaten Bima?

- Apakah Kompetensi, Kompensasi dan Kepuasan Kerja Berpengaruh Simultan Terhadap Motivasi Kerja Relawan Taruna Siaga Bencana (TAGANA) Dinas Sosial Kabupaten Bima?
Vol. 6. No. 2. Oktober 2020

p-ISSN: 2442-9511 e-ISSN: 2656-5862

\section{Tujuan Penelitian}

Sesuai dengan rumusan masalah di atas, maka tujuan dari penelitian ini adalah untuk :

- Menganalisis Pengaruh Kompetensi Terhadap Motivasi Relawan Taruna Siaga Bencana (TAGANA) Dinas Sosial Kabupaten Bima

- Menganalisis Pengaruh Kompensasi Terhadap Motivasi Kerja Relawan Taruna Siaga Bencana (TAGANA) Dinas Sosial Kabupaten Bima.

- Menganalisis Pengaruh Kepuasan Kerja Terhadap Motivasi Kerja Relawan Taruna Siaga Bencana (TAGANA) Dinas Sosial Kabupaten Bima.

- Menganalisis Pengaruh Simultan Kompetensi, Kompensasi dan Kepuasan Kerja Terhadap Motivasi Kerja Relawan Taruna Siaga Bencana (TAGANA) Dinas Sosial Kabupaten Bima.

\section{TINJAUAN PUSTAKA \\ Motivasi}

\section{Motivasi Abraham Maslow}

Abraham Maslow dikutip oleh Mangkunegara (2011:173) mengemukakan bahwa pada dasarnya semua manusia memiliki kebutuhan pokok.Ia menunjukkannya dalam lima tingkatan yang berbentuk piramid, orang memulai dorongan dari tingkatan terbawah. Lima tingkat kebutuhan itu dikenal dengan sebutan Hirarki Kebutuhan Maslow, dimulai dari kebutuhan biologis dasar sampai motif psikologis yang lebih kompleks; yang hanya akan penting setelah kebutuhan dasar terpenuhi. Kebutuhan pada suatu peringkat paling tidak harus terpenuhi sebagian sebelum kebutuhan pada peringkat berikutnya menjadi penentu tindakan yang penting.

\section{Motivasi Mc Cleland}

Menurut David Mc Cleland yang dikutip oleh Mangkunegara (2011:142) terdapat 
Jurnal Ilmiah Mandala Education

http://ejournal.mandalanursa.org/index.php/JIME/index

terakreditasi Peringkat 4 (No. SK: 36/E/KPT/2019)

tiga macam kebutuhan yang perlu diperhatikan pegawai yaitu : Kebutuhan akan prestasi (needs for achievement $=n$ Ach), kebutuhan akan kelompok pertemanan (needs for affliliation = nAff) dan

kebutuhan akan kekuasaan (needs for power = nPower), dimana apabila kebutuhan seseorang terasa sangat mendesak, maka kebutuhan itu akan memotivasi orang tersebut untuk berusaha keras memenuhinya. Berdasarkan teori ini kebutuhan-kebutuhan tersebut dapat dibangun dan dikembangkan melalui pengalaman dan pelatihan. Orang yang tinggi dalam nAch akan lebih menyukai pekerjaan dengan tanggung jawab individu, umpan balik dari kinerja, dan tujuan yang menantang.

\section{Teori Dua Faktor Herzberg}

Hasibuan (2010:88) menjelaskan Teori Dua Faktor (Two-Factor Theory) Frederick Herzberg merupakan kerangka kerja lain untuk memahami implikasi motivasional dari lingkungan kerja dan ada dua faktor di dalam teori ini yaitu: faktor-faktor higienis (sumber ketidakpuasan) dan faktor-faktor pemuas (sumber kepuasan) dalam teorinya Herzberg menyakini bahwa kepuasan kerja memotivasi pada kinerja yang lebih baik. Faktor higienis seperti kebijakan organisasi, supervisi dan gaji dapat menghilangkan ketidakpuasan. Faktor ini berhubungan erat dengan pekerjaan. Perbaikan hubungan pekerjaan tidak mengarah pada kepuasan yang lebih besar, tetapi diharapkan akan mengurangi ketidakpuasan. Dilain pihak, motivator atau pemuas seperti pencapaian, tanggung jawab dan penghargaan mendukung pada kepuasan kerja. Motivator berhubungan erat dengan kerja itu sendiri atau hasil langsung yang diakibatkannya, seperti peluang promosi, peluang pertumbuhan personal, pengakuan tanggung jawab dan prestasi. Perbaikan dalam isi pekerjaan mendorong pada peningkatan kepuasan dan motivasi untuk bekerja lebih baik.
Vol. 6. No. 2. Oktober 2020

p-ISSN: 2442-9511 e-ISSN: 2656-5862

\section{Teori X dan Y}

Teori motivasi milik Douglas McGregor mengemukakan dua pandangan yang nyata mengenai manusia, yakni: pandangan pertama pada dasarnya negatif disebut Teori $\mathrm{X}$, dan yang lain pada dasarnya positif disebut Teori Y. McGregor menyimpulkan bahwa pandangan seorang pemimpin mengenai sifat manusia didasarkan atas beberapa kelompok asumsi tertentu, dan bahwa mereka cenderung membentuk perilaku mereka terhadap pegawai berdasarkan asumsi-asumsi tersebut. Menurut Teori $\mathrm{X}$, asumsi negatif yang dimiliki yakni:

- Karena pegawai tidak menyukai pekerjaan, mereka harus dipaksa, dikendalikan, atau diancam dengan hukuman untuk mencapai tujuantujuan.

- Pegawai akan menghindari tanggung jawab dan mencari perintah formal bilamana mungkin.

- Sebagian pegawai menempatkan keamanan di atas semua faktor lain yang terkait pekerjaan dan menunjukkan sedikit ambisi.

Kontras dengan pandangan negatif tersebut diatas, McGregor membuat asumsi positif yang disebutnya Teori $\mathrm{Y}$ yaitu:

- Pegawai menganggap kerja sebagai hal yang menyenangkan, seperti halnya istirahat atau bermain.

- Pegawai akan berlatih mengendalikan diri, dan emosi untuk mencapai berbagai tujuan.

- Pegawai akan bersedia belajar untuk menerima, bahkan belajar lebih bertanggung jawab.

\section{Kompetensi Kerja}

Menurut Finch dan Crunkilton dikutip oleh Mangkunegara (2011:328) kompetensi adalah penguasaan terhadap suatu tugas, keterampilan, sikap, dan apresiasi yang diperlukan untuk menunjang keberhasilan. Hal itu menunjukkan bahwa kompetensi mencakup tugas, keterampilan sikap dan apresiasi yang harus dimiliki peserta didik untuk dapat 
Jurnal Ilmiah Mandala Education

http://ejournal.mandalanursa.org/index.php/JIME/index

terakreditasi Peringkat 4 (No. SK: 36/E/KPT/2019)

melaksanakan tugas - tugas pembelajaran sesuai dengan jenis pekerjaan tertentu.

Menurut Zwell (2011:136) terdapat tujuh derterminan membentuk kompetensi, yaitu:

- Kepercayaan dan nilai seseorang terhadap sesuatu sangat berpengaruh terhadap sikap dan perilaku seseorang.

- Keahlian/keterampilan, aspek ini memegang peranan sangat penting dalam membentuk kompetensi.

- Pengalaman merupakan elemen penting dalam membentuk penguasaan kompetensi seseorang terhadap tugas.

- Karakteristik Personal seseorang turut berpengaruh terhadap kompetensi seseorang.

- Motivasi seseorang terhadap suatu pekerjaan atau aktivitas akan berpengaruh terhadap hasil yang dicapai.

- Isu-isu emosional hambatan dan blok-blok emosional sering kali dapat membatasi penguasaan kompetensi.

- Kapasitas intelektual seseorang akan berpengaruh terhadap penguasaan kompetensi.

\section{Kompensasi Kerja}

Kompensasi merupakan pengeluaran dan biaya bagi perusahaan. Perusahaan mengharapkan agar kompensasi yang dibayarkan memperoleh kompensasi prestasi kerja yang lebih besar dari karyawan. Jadi, nilai prestasi kerja karyawan harus lebih besar dari kompensasi yang dibayar perusahaan, supaya perusahaan mendapatkan laba dan kontinuitas perusahaan terjamin.Jelaslah pentingnya masalah kompensasi ini untuk karyawan dan perusahaan. Yoder (dalam Hasibuan, 2010:117), mengemukakan "The payment made to member of work teams for their participation," artinya balas jasa membuat anggota tim kerja dapat bekerja sama dan berprestasi.
Kompensasi dipergunakan oleh pekerja untuk memenuhi kebutuhan-kebutuhan hidup. Besarnya kompensasi mencerminkan status, pengakuan, dan tingkat pemenuhan kebutuhan yang dinikmati oleh pekerja bersama keluarganya.Jika kompensasi yang diterima besar berarti tugas dan tanggung jawabnya juga semakin yang besar, statusnya semakin baik, dan pemenuhan kebutuhan semakin banyak pula. Menurut Dessler (2009) disinilah letak pentingnya kompensasi bagi pekerja sebagai seorang penjual tenaga (fisik dan pikiran). Tujuan pemberian kompensasi (balas jasa) antara lain meningkatkan kepuasan dan motivasi, disiplin dan stabilitas kerja.

\section{Kepuasan Kerja}

Handoko (2011:193) menyatakan bahwa kepuasan kerja (job satisfaction) adalah keadaan emosional yang menyenangkan atau tidak menyenangkan bagaimana para pekerja memandang pekerjaan mereka. Kepuasan kerja mencerminkan perasaan seseorang terhadap pekerjaannya.

Menurut Robbins dan Judge (2010:174) konsekuensi ketika pegawai tidak menyukai pekerjaan mereka dengan respons-respons sebagai berikut:

- Keluar (exit): Perilaku yang ditujukan untuk meninggalkan organisasi, termasuk mencari posisi baru dan mengundurkan diri.

- Aspirasi (voice): Secara aktif dan konstruktif berusaha memperbaiki kondisi, termasuk menyarankan perbaikan, mendiskusikan masalah dengan atasan, dan beberapa bentuk aktivitas serikat kerja.

- Kesetiaan (loyality): Secara pasif tetapi estimasi menunggu membaiknya kondisi, termasuk membela organisasi ketika berhadapan dengan kecaman eksternal dan memercayai orgnanisasi dan manajemennya untuk "melakukan hal yang benar".

- Pengabaian (neglect): Secara pasif membiarkan kondisi menjadi lebih buruk, termasuk ketidakhadiran atau keterlambatan 
Jurnal Ilmiah Mandala Education

http://ejournal.mandalanursa.org/index.php/JIME/index

terakreditasi Peringkat 4 (No. SK: 36/E/KPT/2019)

yang terus-menerus, kurangnya usaha, dan meningkatnya angka kesalahan.

\section{Kerangka Pikir Penelitian}

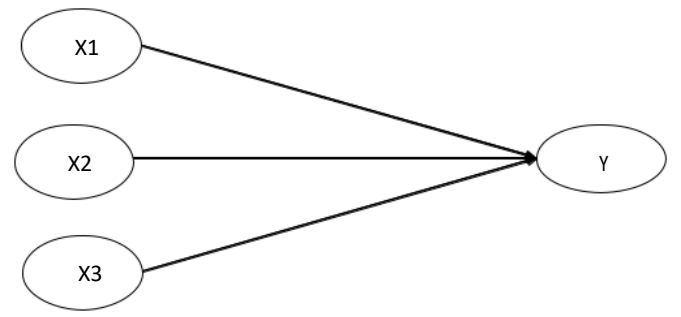

Gambar. Kerangka Pikir Penelitian

Keterangan:

X1 : Kompetensi Kerja

X2 : Kompensasi Kerja

X3 : Kepuasan Kerja

Y : Motivasi Kerja

\section{Hipotesis Penelitian}

Hipotesis penelitian adalah jawaban teoritis (sementara) atas permasalahan penelitian sampai terbukti/dibuktikan kebenarannya melalui kegiatan penelitian empiris di lapangan. Adapun hipotesis yang diajukan dalam penelitian ini diduga bahwa:

- Kompetensi Kerja Berpengaruh Signifikan Terhadap Motivasi Kerja Relawan Taruna Siaga Bencana (TAGANA) Dinas Sosial Kabupaten Bima

- Kompensasi Kerja Berpengaruh Signifikan Terhadap Motivasi Kerja Relawan Taruna Siaga Bencana (TAGANA) Dinas Sosial Kabupaten Bima.

- Kepuasan Kerja Berpengaruh Signifikan Terhadap MotivasiKerja Relawan Taruna Siaga Bencana (TAGANA) Dinas Sosial Kabupaten Bima.

- Kompetensi Kerja, Kompensasi dan Kepuasan Kerja Secara Simultan Berpengaruh Signifikan Terhadap Motivasi KerjaRelawan Taruna Siaga Bencana (TAGANA) Dinas Sosial Kabupaten Bima.

\section{METODE PENELITIAN}

Penelitian ini menggunakan pendekatan penelitian kuantitatif dengan metode yang digunakan adalah penelitian asosiatif (jika $X$ maka Y). Hubungan yang digunakan adalah hubungan kausal yang bersifat sebab akibat. Hubungan sebab-akibat ini mencerminkan implikasi adanya atau berubahnya satu variabel menyebabkan atau berpengaruh pada variabel yang lain. dengan kata lain desain dalam penelitian ini menjelaskan pengaruh parsial dan simultan variabel independen (kompetensi, kompensasi dan kepuasan kerja,) terhadap motivasi kerja sebagai variabel dependen. Populasi dalam penelitian adalah semua Relawan Taruna Siaga Bencana (TAGANA) Dinas Sosial Kabupaten Bima berjumlah 65 orang yang berlokasi di Jalan Lintas SumbawaBima Provinsi Nusa Tenggara Barat (NTB) semuanya dijadikan sebagai responden penelitian.

Menurut Arikunto (2012:104) jika jumlah populasinya kurang dari 100 orang, maka jumlah sampelnya diambil secara keseluruhan, tetapi jika populasinya lebih besar dari 100 orang, maka bisa diambil 10-15\% atau 20-25\% dari jumlah populasinya. Mengingat jumlah populasi sebanyak 65 orang Relawan Taruna Siaga Bencana (TAGANA) Dinas Sosial Kabupaten Bima, maka adapun teknik pengambalan sampel dalam penelitian ini adalah dengan menggunakan teknik sensus karena semua populasi dijadikan sebagai sampel penelitian.

Analisis deskriptif dilakukan untuk melakukan skala pengkuruan variabel penelitian yang dijabarkan berdasarkan kelas interval, kategori dan ferekuensi dari masingmasing variabel penelitian. Skala pengukuran digunakan untuk mendeskripsikan sikap responden terhadap variabel penelitian. untuk mendeskripsikan variabel penelitian maka langkah yang dilakukan adalah melakukan pengukuran variabel melalui hasil pembobotan 
terhadap masing-masing variabel dengan menggunakan lima skala sikap:

\begin{tabular}{|c|c|c|}
\hline & & Keterangan \\
\hline Skala Sikap & Positif & Negatif \\
\hline Sangat Setuju & 5 & 1 \\
\hline Setuju & 4 & 2 \\
\hline Kurang setuju & 3 & 3 \\
\hline Tidak setuju & 2 & 4 \\
\hline
\end{tabular}

Fingatifak PENELITIAN DA'N PEMBAHASAN

Sebelum instrumen penelitian digunakan sebagai alat pengumpulan data penelitian maka peneliti terlebih dahulu melakukan uji validitas dan reliabilitas. Setelah data-data terkumpul peneliti melakukan analisis menggunakan bantuan program SPSS 16 dengan ringkasan hasil.uji validitas dan reliabilitas motivasi kerja sebesar 0,729 rhitung dan 0,Cronbach's Alpha. Variabel kompetensi 0,682 r-hitung, variabel kompensasi 0,712 r-hitung, variabel kepuasan kerja 0,703 yang artinya seluruh data yang digunakan reliable dan valid.

Sedangkan berdasarkan analisis persyaratan regresi di dapati data sebagai berikut:

\section{Normalitas}

\begin{tabular}{|c|c|c|c|c|c|}
\hline & \multicolumn{3}{|c|}{ One-Sample Kolmogorov-Smirnov Test } & \multirow[b]{2}{*}{ Kepuasan } & \multirow[b]{2}{*}{ Motivasi } \\
\hline & & & & & \\
\hline & & Kompetensi & Kompensasi & Kerja & Kerja \\
\hline $\mathrm{N}$ & & 65 & 65 & 65 & 65 \\
\hline \multirow[t]{2}{*}{ Normal Parameters ${ }^{3}$} & Mean & 83.08 & 81.34 & 67.62 & 81.02 \\
\hline & Std. Deviation & 7.890 & 6.920 & 13.209 & 5.746 \\
\hline Most Extreme & Absolute & .148 & .192 & .187 & .186 \\
\hline \multirow[t]{2}{*}{ Differences } & Positive & .140 & 192 & .108 & 186 \\
\hline & Negative & -.148 & -.116 & -.187 & -.130 \\
\hline Kolmogorov-Smirnov Z & & 1.196 & 1.549 & 1.508 & 1.496 \\
\hline Asymp. Sig. (2-tailed) & & .115 & .217 & .121 & .123 \\
\hline a. Test distribution is $\mathrm{N}$ & rmal. & & & & \\
\hline
\end{tabular}

Data variabel penelitian akan dikatakan berdistribusi normal, jika taraf signifikan kurang dari 0.05 Kolmogorov-Smirnova. Dengan demikian maka semua variabel penelitian dinyatakan berdistribusi normal sebagaimana data yang ditapil dibawah ini.

\section{Multikolinieritas}

\begin{tabular}{|c|c|c|c|c|c|c|c|c|}
\hline & $\Rightarrow$ & \multicolumn{3}{|c|}{ Coefficients } & & & & \\
\hline & \multicolumn{2}{|c|}{ Unstandardized } & \multicolumn{2}{|c|}{ Standardized } & & & \multicolumn{2}{|c|}{ Collinearity } \\
\hline & \multicolumn{2}{|c|}{ Coefficients } & \multicolumn{2}{|c|}{ Coefficients } & & & \multicolumn{2}{|c|}{ Statistics } \\
\hline & & & & & & & Toleranc & \\
\hline Model & B & Std. Error & Beta & & $\mathrm{t}$ & Sig. & e & VIF \\
\hline 1 (Constant) & 49.806 & 8.094 & & & 6.153 & .000 & & \\
\hline Kompetensi & .210 & .099 & & 289 & 2.131 & .037 & .668 & 1.498 \\
\hline Kompensasi & .083 & .118 & & 100 & .704 & .484 & .610 & 1.640 \\
\hline Kepuasan Kerja & .104 & .054 & & 238 & 1.905 & .062 & .783 & 1.277 \\
\hline a. Dependent Vari & Motivasi r & & & & & & & \\
\hline
\end{tabular}

nilai tolerance kurang dari 10 dan VIP lebih besar dari 10 maka tidak terjadi multikolinearitas.

\section{Linieritas}

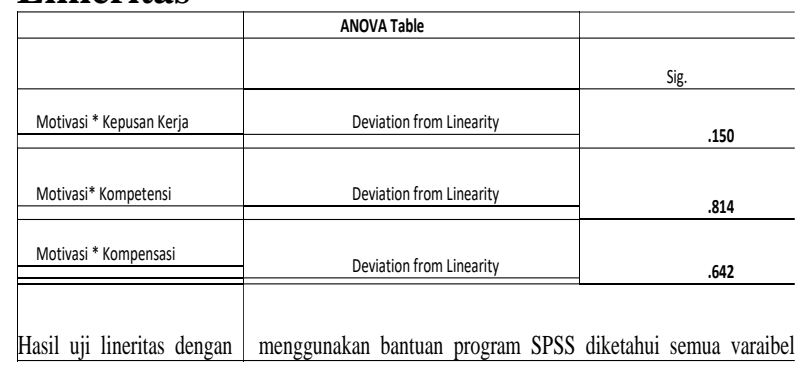

memiliki hubungan yang linieritas karena nilai sig Deviation from Linearity lebih besar dari 0.05 .

\section{Analisis Regresi Berganda}

Analisis regresi berganda bertujuan untuk menganalisis sejauhmana pengaruh parsial maupun simultan dari masing-masing variabel bebas yaitu kompentensi, kompensasi dan kepuasan kerja terhadap variabel terikat yaitu motivasi kerja. Model persamaan regresi menggunakan rumus: $\mathrm{Y}=\alpha+\beta 1 \mathrm{X} 1+\beta 2 \mathrm{X} 2+$ $\beta 3 \mathrm{X} 3$ dan didapati hasilnya sbb:

\begin{tabular}{|l|c|c|r|} 
Variabel Independen & Koefisien Parsial & t -hitung & Sig. \\
\hline Kompetensi Kerja & 0,386 & 3.318 & 0,00 \\
\hline Kompensasi & 0,565 & 5.440 & 0,00 \\
\hline Kepusan Kerja & 0,430 & 3.777 & 0,00 \\
\hline Konstan $(\alpha)$ & & $\mathbf{4 9 . 0 8 6}$ & \\
\hline
\end{tabular}

Sedangkan untuk analisis pengaruh parsial didapati hasilnya sbb:

\begin{tabular}{|r|r|c|c|c|r|}
\hline & & & \multicolumn{2}{|c|}{ Model Summary } & \\
\hline Model & $\mathrm{R}$ & R Square & F-hitung & Sig. \\
\cline { 1 - 2 } 1 & .615 & .378 & 12.395 & 0,00 \\
\hline
\end{tabular}

a. Predictors: (Constant), Kompensasi Kerja, , Kepuasan Kerja Kompetensi Kerja 
b. Dependent Variable: Motivasi Kerja

\section{KESIMPULAN}

Berdasarkan uraian di atas dapat disimpulkan bahwa: Semakin baik kompetensi maka akan semakin baik motivasi kerja atau untuk meningkatkan motivasi kerja TAGANA harus dibarengi dengan peningkatan kompetensi kerja. Selain itu, Semakin tinggi kompensasi yang diterima maka semakin tinggi pula motivasi kerja. Pemberian kompensasi yang tinggi maka akansemakin tinggi pula motivasi kerja TAGANA. Semakin puas TAGANA dalam bekerja maka menyebakan samakin tinggi motivasi kerja. Artinya semakin tinggi tingkat kepuasan kerja maka akan semakin tinggi pula motivasi kerja TAGANA. Dengan demikian, secara bersama-sama kompetensi, kompensasi dan kepuasan kerja memiliki pengaruh signifikan terhadap motivasi kerja TAGANA. Artinya untuk meningkatkan motivasi kerja, perlu adanya peningkatan bersama antara komptensi, kompensasi dan kepuasan kerja.

\section{DAFTAR PUSTAKA}

Arikunto, Suharsimi. 2012. Prosedure Penelitian Suatu Pendekatan Praktek. Jakarta: Rineka Cipta

Dessler, Gary. (2011). Manajemen Sumber Daya Manusia. Penerbit Indeks, Jakarta Hasibuan. 2010.Manajemen Sumber Daya Manusia. Edisi Revisi. Jakarta : Bumi Aksara. Handoko, H. T. 2009. Manajemen Personalia dan Sumberdaya Manusia. Edisi II, Cetakan Keempat Belas. Yogyakarta: BPFE.

Mangkunegara, A.P. 2011. Manajemen Sumber Daya Manusia Perusahaan. Bandung: Refika Aditama.

Robbins, dan Judge. 2010. Perilaku Organisasi. Jakarta: Salemba empat.

Zwell, M. 2013. Creating a Culture of Competence. New York: John Wiley \& Sons, Inc. 